\title{
Root biomass and soil carbon response to growing perennial grasses for bioenergy
}

\author{
Leonard C. Kibet ${ }^{1 *}$, Humberto Blanco-Canqui ${ }^{1}$, Robert B. Mitchell ${ }^{2}$ and Walter H. Schacht ${ }^{1}$
}

\begin{abstract}
Background: Dedicated bioenergy crops such as switchgrass (Panicum virgatum L.), miscanthus [Miscanthus $x$ giganteus (Mxg)], indiangrass [Sorghastrum nutans (L.) Nash], and big bluestem (Andropogon gerardii Vitman) can provide cellulosic feedstock for biofuel production while maintaining or improving soil and environmental quality. To better understand bioenergy crop effects on soils, we studied changes in soil properties of a Tomek silt loam under inorganic fertilization of switchgrass after 4 years and warm-season grass monocultures and mixtures after 6 years in eastern Nebraska.

Methods: The first experiment had two study factors: two switchgrass harvest dates (August and November) and nitrogen $(N)$, phosphorus $(P)$, and potassium (K) fertilization rates. Nitrogen fertilizer levels $\left(0,60\right.$, and $\left.120 \mathrm{~kg} \mathrm{~N} \mathrm{ha}^{-1}\right)$ were the main plots, while P levels $\left(0,22\right.$, and $\left.44 \mathrm{~kg} \mathrm{P} \mathrm{ha}^{-1}\right)$ were the split plots and $\mathrm{K}$ levels $\left(0,11\right.$, and $\left.22 \mathrm{~kg} \mathrm{~K} \mathrm{ha}^{-1}\right)$ were the split-split plots. The second experiment included six bioenergy feedstocks comprised of four monocultures [switchgrass (cv. Shawnee and an experimental strain tracked as Kanlow N1), indiangrass (Chief), and miscanthus (Mxg)] and two mixtures [big bluestem (Goldmine) + indiangrass (Warrior) + switchgrass (Shawnee) and big bluestem (Bonanza) + indiangrass (Scout) + switchgrass (Shawnee)]. Soil samples were analyzed for root biomass, soil organic C (SOC), total N, bulk density, aggregate stability, and pH.

Results: In the first experiment, inorganic fertilization and harvest dates had no effect on switchgrass root biomass, SOC pools, soil aggregate stability, and other properties. In the second experiment, cumulative root biomass under Chief indiangrass monoculture was lower than that under other grass monocultures and mixtures except miscanthus. These results suggest that inorganic fertilization and harvest dates do not affect soil properties in the short term, but Chief indiangrass monoculture may have lower root biomass than other grasses.

Conclusions: Overall, fertilization management did not induce changes in root biomass and soil properties, but Chief indiangrass monoculture had lower cumulative root biomass compared with mixtures and switchgrass monocultures, suggesting that cultivar selection will affect root biomass accumulation. Further monitoring is needed to determine long-term changes in root biomass and soil properties under these bioenergy crop systems.
\end{abstract}

Keywords: Bioenergy, Perennial warm-season grasses, Monocultures, Mixtures, Root biomass, Soil organic carbon, Total nitrogen

\footnotetext{
* Correspondence: Ikibet2@unl.edu

${ }^{1}$ Department of Agronomy and Horticulture, University of Nebraska-Lincoln, Lincoln, NE 68583, USA

Full list of author information is available at the end of the article
}

\section{至 Springer}

C 2016 Kibet et al. Open Access This article is distributed under the terms of the Creative Commons Attribution 4.0 International License (http://creativecommons.org/licenses/by/4.0/), which permits unrestricted use, distribution, and reproduction in any medium, provided you give appropriate credit to the original author(s) and the source, provide a link to the Creative Commons license, and indicate if changes were made. 


\section{Background}

Dedicated bioenergy crops such as native perennial warm-season grass monocultures and mixtures may provide abundant biomass for biofuel production. However, their effects on soil ecosystem services have not been widely documented under different soil types, management scenarios, and climatic conditions. Although perennial bioenergy crops generally improve soil properties such as soil organic C (SOC), and soil structural properties compared with row crops [3,9], little information is available on the differences in soil properties between perennial grass monocultures and mixtures and among inorganic fertilization levels. This knowledge is crucial for the development of sustainable bioenergy cropping systems as soil properties are an integral component of soil productivity.

Perennial warm-season grasses may improve soil properties by virtue of their fibrous and extensive root network. Warm-season grass species and varieties may, however, differ in their root biomass and distribution. Some studies have suggested that species in diverse communities might alter the depth distribution of roots in response to the density and uniqueness of neighboring roots $[9,28,32]$. In pot experiments, von Felten and Schmid [48] found that mixtures of grass species increased root biomass in deeper soil depths than monocultures. Also, Cong et al. [8] reported that a mixture of eight grasses that consisted of four grass species (Agrostis capillaris L., Anthoxanthum odoratum L., Festuca rubra L., and Holcus lanatus L.) and four forbs (Centaurea jacea L., Leucanthemum vulgare Lam., Plantago lanceolata L., and Rumex acetosa L.) increased root biomass more than their monocultures (6.85 versus 4.33 $\mathrm{Mg} \mathrm{ha}^{-1}$ ).

One potential impact of bioenergy production systems is SOC accumulation. This is important because SOC can enhance soil ecosystem services and increase soil productivity [2]. Perennial grasses may have different impacts on above- and belowground biomass production and SOC accumulation, depending on grass species, varieties, and mixtures, but such impacts have not been widely studied. Accumulation of $\mathrm{C}$ and $\mathrm{N}$ in the soil can be complex and depends on many variables such as soil type, management practices, residue quality, precipitation input, and harvest treatments $[1,10]$. For example, soils with low initial SOC concentration may have greater potential to accumulate SOC under perennial energy crops.

Perennial grass monocultures and mixtures may affect SOC and other soil properties differently. Blanco-Canqui [4] reported that mixtures of perennial warm-season grasses have the potential to store more SOC than monocultures. In a 12-year study in Minnesota, Fornara and Tilman [12] reported that high-diversity mixtures of perennial grass species can store, on average, $500 \%$ more SOC and $600 \%$ more $\mathrm{N}$ than monocultures of the same species. In an 11-year study, perennial warm-season grass mixtures increased SOC stocks by $18 \%$ and N stocks by $16 \%$ compared with monocultures of the same species [8]. The large increase of SOC under perennial mixtures may be due to the greater grass diversity, more abundant root biomass, and deeper distribution of $\mathrm{C}$-enriched roots relative to monocultures. In a 3-year study, Bonin et al. [6] showed, however, no effect of multiple species mixtures of perennial warm-season grasses on SOC, suggesting that perennial mixtures may not increase SOC stocks in the short term relative to monocultures.

Additionally, since aboveground biomass is harvested for bioenergy, growing perennial grasses may deplete soil nutrients. Nutrient removal from the soil may vary because of differences in biomass production, cultivars, weather, soil type, and management practices [42]. For example, Newton et al. [36] showed that grasses have greater ability to absorb soil nutrients than broadleaf forages, implying that grasses differ in their potential to remove nutrients from the soil. Also, in a study comparing nutrient removal rates by perennial grasses, giant reed (Arundo donax L.) had the highest aboveground biomass yield and the highest nutrient ( N, P, and $\mathrm{K}$ ) concentrations and removal rates compared to switchgrass, giant miscanthus, weeping lovegrass [Eragrostis curvula (Shrad.) Nees], kleingrass (Panicum coloratum L.), and Johnsongrass [Sorghum halepense (L.) Pers.] [23], suggesting that aboveground biomass is correlated with soil nutrient removal.

Production of perennial warm-season grasses for bioenergy consumes soil nutrients and needs constant supplementation of nutrients through inorganic fertilization [23]. Inorganic fertilization increases aboveground biomass production of perennial warm-season grasses [19, 25, 47]; however, its effect on root biomass, SOC stocks, and other soil properties is unclear [19]. Root biomass response to $\mathrm{N}$ application is variable. Ma et al. [28] found that fertilization (224 kg N ha ${ }^{-1}$ ) of 4-year-old switchgrass stands in Alabama had no effect on root biomass relative to control $\left(0 \mathrm{~kg} \mathrm{~N} \mathrm{ha}^{-1}\right)$. Garten et al. [15] also reported no effect of $\mathrm{N}$ fertilization on switchgrass root biomass in a 5-year study. In contrast, Heggenstaller et al. [19] found that high rates of fertilization $\left(220 \mathrm{~kg} \mathrm{~N}^{-1}\right.$ ) reduced root biomass in 3or 4-year-old stands of switchgrass in Iowa. Similarly, fertilization-induced changes in SOC storage are inconsistent. Previous studies indicated that SOC increased [20, 39], decreased [24, 30], or were unaffected [29, 33] following fertilization of perennial grasses.

The objectives of this study were to assess the following: (1) the impact of different rates and mixtures of $\mathrm{N}$, $\mathrm{P}$, and $\mathrm{K}$ fertilization and harvest date on switchgrass root biomass, SOC, total N, and other soil properties, and (2) soil-profile distribution of root biomass, SOC, bulk density, and total $\mathrm{N}$ under perennial warm-season 
grass monocultures and mixtures. Our first hypothesis was that fertilization of switchgrass increases root biomass, SOC, and total $\mathrm{N}$ pools relative to non-fertilized plots. Our second hypothesis was that perennial warmseason grass mixtures increase root biomass, SOC, and total $\mathrm{N}$ pools compared with warm-season grass monocultures. Perennial warm-season grasses need to be in production for at least 5 years to be economically feasible [37]. Therefore, our study was designed to assess soil response to growing perennial grasses during the above timeframe. Soil response to perennial grasses in the short term ( $<5$ years) may not be measurable until the grasses reach their full potential at about 5 years [37].

\section{Methods}

\section{Study site}

The study was conducted on two sites seeded to perennial warm-season grasses at the University of NebraskaLincoln's Agricultural Research and Development (ARDC) Center near Mead, NE $\left(41.2261^{\circ} \mathrm{N}, 96.4883^{\circ}\right.$ W). The soil for both sites is classified as Tomek silt loam (Fine, smectitic, mesic Pachic Argiudolls). The Tomek series consists of very deep well-drained soils formed in loess with clay content between 24 and $35 \%$, while the sand content is $<10 \%$ in the $\mathrm{A}$ and $\mathrm{AB}$ horizons. Experiment I was established in 2006 and was seeded to switchgrass (cv. Shawnee) monocultures and had two study factors: two biomass harvest dates (August and November) and N, P, and $\mathrm{K}$ fertilization rates. This study was seeded at a rate of 320 pure live seed (PLS) per meter square. The main plot was 3.3 by $3 \mathrm{~m}$, while the split-split plots were 1.1 by $3 \mathrm{~m}$. Treatments were applied to plots in a randomized complete block, split-split-plot design with three replications. Fertilizer treatments were applied beginning in 2010, 4 years after field establishment. The main plot treatment was a level of $\mathrm{N}$ fertilization $\left(0,60\right.$, and $\left.120 \mathrm{~kg} \mathrm{~N} \mathrm{ha}^{-1}\right)$. The split plot treatment was a level of $\mathrm{P}$ fertilization $(0,22$, and 44. $\mathrm{kg} \mathrm{P} \mathrm{ha}{ }^{-1}$ ), and the split-split plot treatment was a level of $\mathrm{K}$ fertilization $\left(0,11\right.$, and $\left.22 \mathrm{~kg} \mathrm{~K} \mathrm{ha}^{-1}\right)$. Nitrogen was applied as urea (46-0-0), $\mathrm{P}$ was applied as triple superphosphate (0-16-0), and $\mathrm{K}$ was applied as potassium sulfate (0-0-50). All fertilizer treatments were broadcast with a drop spreader. Plots were harvested at a $10 \mathrm{~cm}$ cutting height with a small-plot flail harvester (Carter Manufacturing, Brookston, IN) either at anthesis (near August 1) or after a killing frost each year by harvesting in the direction of the split-split plot treatment.

Experiment II was established in 2009 and was seeded with 29 perennial grass monocultures and mixtures and replicated four times in a randomized complete block design. Our study evaluated soil properties for only six of the 29 high-yielding grasses (four monocultures and two mixtures). The monocultures evaluated were switchgrass (cv. Shawnee), switchgrass (Kanlow N1), indiangrass (Chief), and miscanthus (Mxg). The mixtures included grass mixtures of [big bluestem (Goldmine) + indiangrass (Warrior) + switchgrass (Shawnee)] (Mixture 1) and [big bluestem (Bonanza) + indiangrass (Scout) + switchgrass (Shawnee)] (Mixture 2) in four field replicates. The mixtures will hereafter be referred to as mixture 1 and mixture 2 for discussion purposes. Experimental units were $1.1 \times 3-\mathrm{m}$ plots seeded to the monocultures or the mixtures at a rate of 320 PLS per square meter. The miscanthus used was the Illinois Miscanthus $x$ giganteus clone started from rhizomes, grown in a greenhouse, and transplanted into the plots from pots at 12 plants per plot. Immediately after planting or transplanting, all plots were sprayed with 0.24 $\mathrm{L} \mathrm{ha}^{-1}$ of Paramount (quinclorac: 3, 7dichloro-8-quinolinecarboxylic acid) plus $0.95 \mathrm{~L} \mathrm{ha}^{-1}$ atrazine (2-chloro-4 ethylamino-6-isopropylamino-s-triazine) to control grassy weeds. Broadleaf weeds were sprayed as needed, typically with 2, 4-D (2, 4-dichlorophenoxyacetic acid) at $0.95 \mathrm{~L} \mathrm{ha}^{-1}$. No fertilizer was applied in the seeding year, but all plots were fertilized with $112 \mathrm{~kg} \mathrm{~N} \mathrm{ha}^{-1}$ as urea (46-0-0) after growth initiation in April or May of each year. Harvesting was done as described for experiment I (N, P, and K study) above. Data on aboveground biomass yield for both experiments (I and II) will be reported in a companion paper. The focus of this paper was on root biomass and soil properties.

\section{Soil sampling}

Under experiment I, we measured root biomass, SOC, total $\mathrm{N}$, bulk density, soil aggregate stability, and $\mathrm{pH}$. Under experiment II, we measured root biomass, SOC, total $\mathrm{N}$, and bulk density. We included soil aggregate stability and $\mathrm{pH}$ measurements in experiment I to study possible effects of inorganic fertilization on these two properties. Previous studies on inorganic fertilization of row crops reported decreased $\mathrm{pH}$ and mixed effects on aggregate stability with fertilization $[5,26]$.

Soil samples were collected in June 2014 from experiment I and June 2015 from experiment II. In experiment I $(\mathrm{N}, \mathrm{P}$, and $\mathrm{K}$ study), four soil cores were collected from each plot using a 3-cm diameter hand probe for the $0-10$ - and 10-20-cm depths. Two core samples were composited for soil analyses, and the other two cores were composited for root biomass analysis. In experiment II (monocultures and mixtures), six soil cores (4.57 cm diameter) per plot were collected using a tractor-mounted Giddings probe (Giddings Machine Company, Inc. Windsor, CO). We collected three soil cores from the center of the plants and three between plants to a depth of $100 \mathrm{~cm}$ per plot and sliced at $0-10,10-20,20-40,40-60$, and $60-80$ and $80-100 \mathrm{~cm}$ depths. The six cores were composited, placed in paper bags, air-dried for $72 \mathrm{~h}$, and analyzed. One hundred grams 
of soil without roots was carefully extracted from the composite sample for the analyses of SOC and total $\mathrm{N}$ concentration. The remaining soil sample was used for root biomass analysis.

\section{Measurement of soil properties}

Root biomass was analyzed on air-dried soil samples for both experiments. The samples were weighed, soaked, and roots rinsed in tap water over a $0.5-\mathrm{mm}$ sieve. Sand and debris were hand-sorted from root material while rinsing in tap water. Roots including crown, rhizomes, and fine roots recovered were placed in an aluminum pan and oven-dried at $60{ }^{\circ} \mathrm{C}$ for root biomass determination [32].

Soil samples collected for experiment I were analyzed for wet aggregate stability using the wet sieving method described by Nimmo and Perkins [35]. Soil samples were passed through 4.75- and 8-mm sieves to obtain soil aggregates with diameters between 4.75 and $8 \mathrm{~mm}$. Fifty grams of aggregates were weighed, placed on top of a nest of sieves with 4.75 - and $0.25-\mathrm{mm}$ openings, immersed in water, and saturated by capillarity for $10 \mathrm{~min}$ before wet sieving for another $10 \mathrm{~min}$. A mechanical sieving device was used to oscillate the column of sieves with a stroke of $3 \mathrm{~cm}$. Aggregates remaining in each sieve were transferred to pre-weighed beakers and dried at $105{ }^{\circ} \mathrm{C}$. Amount of water-stable aggregates was expressed as the percentage of soil remaining on the sieve after 10 min relative to the initial mass of soil used. The amount of water-stable aggregates was corrected for sand content and reported as macro- and micro-aggregates. Aggregates with diameters $>0.25 \mathrm{~mm}$ were classified as macro-aggregates, while aggregates with diameters $<0.25 \mathrm{~mm}$ were classified as micro-aggregates [45].

All other soil samples were air-dried and sieved $(2 \mathrm{~mm})$ before analysis. Soil organic $\mathrm{C}$ and total $\mathrm{N}$ concentrations were determined on soil ground on a roller mill before analysis by dry combustion using a LECO CN 2000 analyzer (Leco Corp., St Joseph, MI; [34]). Baseline data on SOC concentration were not available for either experiment. Soil particle-size distribution was determined using the hydrometer method [17]. Soil particle-size distribution did not significantly differ among treatments and between the two experiments. Averaged across both experiments and treatments, soil had $15 \%$ sand, $36 \%$ clay, and $49 \%$ silt for the 0 - to $10-\mathrm{cm}$ depth and was classified as silty clay loam. The bulk density was determined using the core method for each soil depth [38]. Soil pH was measured on soil and water in a 1:2 ratio using Thermo Orion $525 \mathrm{~A}+\mathrm{pH} / \mathrm{mV}$ meter (Thermo-electron Corporation, $\mathrm{MN}$ ). The mixture was allowed to stand for at least $1 \mathrm{~h}$, stirred every 10 to $15 \mathrm{~min}$ to allow the $\mathrm{pH}$ of the soil slurry to stabilize before measuring $\mathrm{pH}$ [44].
Data were analyzed by SAS PROC UNIVARIATE to test their normality and equal variance distribution. Root biomass data required logarithmic transformation to achieve normality. Data were reported as geometric means for discussion purposes. Analysis of variance in PROC MIXED in SAS [43] and least significant difference test were used to assess treatment differences. Fertilization effects were analyzed by harvest date and soil depth. Nitrogen, P, and K fertilization levels were the fixed variables, while replications were the random variables in the analysis. Differences among treatments were studied at the 0.10 probability level.

\section{Results and discussion Inorganic fertilization (experiment I) Root biomass}

Inorganic fertilization of switchgrass had no effect on root biomass. Mean root biomass across N, P, and K fertilization rates was $3.87 \pm 1.59 \mathrm{Mg} \mathrm{ha}^{-1}$ (mean $\pm \mathrm{SD}$ ) for the 0 - to 20-cm depth. These results did not support our hypothesis stating that inorganic fertilization will increase root biomass of switchgrass. The lack of differences in root biomass may be due to the following: (1) the relatively short period of fertilization (4 years) and (2) the use of a highly productive soil in this experiment, which possibly reduced the effects of fertilization on root biomass. We hypothesize that inorganic fertilization would have significant effects on root biomass if switchgrass were managed in marginally productive lands with low organic matter content.

Previous studies of fertilization on root biomass have reported similar findings to our study. For example, after 5 years, $\mathrm{N}$ fertilization of switchgrass did not affect root biomass in a study in western Tennessee [15]. Similarly, after 4 years, $\mathrm{N}$ fertilization did not affect root biomass of perennial warm-season grasses across three sites in Ohio [21]. Also, in another study in western Tennessee, $\mathrm{N}$ fertilization of switchgrass reduced root biomass in the spring but had no effect in the fall after 4 years [22]. Some studies have indicated that addition of fertilizers to highly productive soils can enhance biomass production without changing the root systems [46]. Previous studies and the present study suggest that inorganic fertilization of switchgrass may not generally increase root biomass relative to control without fertilization in the short term.

\section{Soil organic carbon and other soil properties}

Inorganic fertilization of switchgrass and harvest dates (August and November) had no effect on SOC pools and other soil properties. Because trends in mean SOC concentrations and pools were similar, only SOC pools are presented. Mean SOC across fertilization levels was $24.3 \pm 3.7 \mathrm{Mg} \mathrm{C} \mathrm{ha}^{-1}$ at the 0 - to $10-\mathrm{cm}$ depth and 27.9.3 $\pm 3.4 \mathrm{MgC} \mathrm{ha}^{-1}$ at the 10 - to $20-\mathrm{cm}$ depth. While 
the lack of fertilization effect may not be surprising, we expected that high fertilization rates would increase SOC pools by increasing root biomass production, but that was not the case. No differences in SOC among N, $\mathrm{P}$, and $\mathrm{K}$ fertilization rates are likely due to no differences in root biomass amount.

Similar to our study after 9 years of another switchgrass experiment at ARDC, fertilization and harvest date had variable effects on SOC [13]. Previous studies have found small or no increase in SOC pools with fertilization $[21,27]$. Corresponding with SOC, inorganic fertilization did not affect soil C:N ratio. Average C:N ratio across N, $\mathrm{P}$, and $\mathrm{K}$ fertilization levels was $10.69 \pm 2.01 \mathrm{ppm}$ at 0 - to 10 -cm depth and $11.74 \pm 1.55 \mathrm{ppm}$ at 10 - to 20 -cm depth. Some studies have indicated that $\mathrm{N}$ fertilization of switchgrass decreases root $\mathrm{C}: \mathrm{N}$ ratio $[15,19]$ by increasing organic matter decomposition, thereby reducing SOC concentration.

Also, inorganic fertilization did not affect soil bulk density and soil $\mathrm{pH}$. Bulk density averaged across fertilization levels ranged from 1.32 to $1.45 \mathrm{~g} \mathrm{~cm}^{-3}$ at the 0 - to $10-\mathrm{cm}$ depth and 1.54 to $1.64 \mathrm{~g} \mathrm{~cm}^{-3}$ at the 10 - to $20-\mathrm{cm}$ depth and the mean $\mathrm{pH}$ was $5.92 \pm 0.21$ at the 0 - to 10 -cm depth and $6.11 \pm 0.44$ at the 10 - to 20 - $\mathrm{cm}$ depth. Under row crops, inorganic fertilization often reduces soil $\mathrm{pH}$ through the release of $\mathrm{H}^{+}$[26], but in our study, under perennial grasses, soil $\mathrm{pH}$ was unaffected by fertilization.

\section{Wet aggregate stability}

Similarly, inorganic fertilization of switchgrass did not affect soil aggregate stability. The amount of macroaggregates among fertilizer levels ranged from 53 to $84 \%$ at the 0 - to $10-\mathrm{cm}$ depth. In row crops, $\mathrm{N}$ fertilization negatively affects wet aggregate stability in some soils. For example, Blanco-Canqui et al. [5] reported that in the 7.5to $45-\mathrm{cm}$ soil depth, soil aggregate stability decreased with an increase in $\mathrm{N}$ application. The decreased aggregate stability with fertilization suggests that the use of $\mathrm{N}$ fertilizers, particularly those that release $\mathrm{NH}_{4}^{+}$, can reduce soil aggregation by dispersing colloids and secondary particles [18] and reducing the amount of microbial biomass [26].

Published studies on the effects of switchgrass fertilization on soil aggregation are few. In Ohio, 4 years of $\mathrm{N}$ fertilization of switchgrass at $202 \mathrm{~kg} \mathrm{~N} \mathrm{ha}^{-1}$ reduced the amount of macro-aggregates at the $0-$ to $5-\mathrm{cm}$ depth compared with non-fertilized plots [22]. The highest $\mathrm{N}$ application rate in the latter study was $202 \mathrm{~kg} \mathrm{~N} \mathrm{ha}{ }^{-1}$, whereas our maximum rate was $120 \mathrm{~kg} \mathrm{~N} \mathrm{ha}^{-1}$, suggesting that higher rates of $\mathrm{N}$ application than that used in our study may reduce soil aggregate stability.

\section{Root biomass of monocultures and mixtures (experiment II) Root biomass}

Perennial grass monocultures and mixtures did not affect the amount of root biomass when data were analyzed by depth interval (Table 1). However, cumulative root biomass under Chief indiangrass monoculture for the 0 - to $100-\mathrm{cm}$ depth was significantly lower than under other grass monocultures and mixtures except miscanthus (Table 1). The indiangrass monoculture had 1.8 times lower $\left(10.63 \mathrm{Mg} \mathrm{ha}^{-1}\right)$ root biomass than the average across all other treatments except miscanthus (19.31 $\mathrm{Mg} \mathrm{ha}^{-1}$; Table 1). The order of cumulative root biomass was the following: mixture $1=$ mixture $2=$ Shawnee switchgrass $=$ Kanlow N1 switchgrass $\geq$ miscanthus $\geq$ Chief indiangrass.

Results showed that mixtures and monocultures that included switchgrass varieties have greater root biomass than the Chief indiangrass monoculture. Switchgrass as a species is considered to be the most adaptable to diverse regions with variable soil and climatic conditions

Table 1 Impact of growing perennial warm-season grasses in monocultures and mixtures on root biomass on a Tomek silt loam in eastern Nebraska after 6 years of management

\begin{tabular}{|c|c|c|c|c|c|c|c|}
\hline \multirow[t]{3}{*}{ Treatments } & \multicolumn{7}{|c|}{ Root biomass $\left(\mathrm{Mg} \mathrm{ha}^{-1}\right)$} \\
\hline & \multicolumn{7}{|c|}{ Depths (cm) } \\
\hline & $\overline{0-10}$ & $10-20$ & $20-40$ & $40-60$ & $60-80$ & $80-100$ & $0-100$ \\
\hline Grass mixture 1 & 11.98 & 1.54 & 2.34 & 1.15 & 1.32 & 0.58 & $18.54 a^{*}$ \\
\hline Grass mixture 2 & 11.64 & 1.34 & 2.38 & 1.73 & 0.87 & 1.06 & $18.17 a$ \\
\hline Shawnee & 14.41 & 1.84 & 1.61 & 1.13 & 0.65 & 0.81 & $20.27 a$ \\
\hline Kanlow N1 & 12.47 & 2.53 & 2.78 & 1.59 & 1.05 & 0.89 & $20.27 a$ \\
\hline Miscanthus (Mxg) & 9.21 & 2.22 & 3.78 & 0.70 & 0.66 & 0.74 & 16.79ab \\
\hline Chief & 6.82 & 1.29 & 1.38 & 1.12 & 0.71 & 0.50 & $10.63 b$ \\
\hline LSD 0.10 & 6.70 & 1.32 & 2.44 & 0.84 & 0.49 & 0.86 & 1.59 \\
\hline
\end{tabular}

The means are back-transformed log values. Perennial warm-season grass monocultures [switchgrass (cv. Shawnee, Kanlow N1), indiangrass (Chief) and Mxg] and grass mixture 1 [big bluestem (Goldmine) + indiangrass (Warrior) + switchgrass (Shawnee)] and grass mixture 2 [big bluestem (Bonanza) + indiangrass (Scout) + switchgrass (Shawnee)]

${ }^{*}$ Numbers followed by different letters within a column show significant differences among treatments at $P \leq 0.10$ 
in the USA including the Midwest [31]. Based on the results, some varieties of indiangrass such as Warrior and Scout may be grown in mixtures of perennial grasses for enhanced root biomass relative to Chief indiangrass alone. While our experiment did not have Warrior and Scout indiangrass varieties grown alone to compare with the Chief indiangrass monoculture, our results appear to suggest that indiangrass grown in monocultures may likely fill less of the soil profile with roots than indiangrass grown in mixtures. Results also suggest that root characteristics may differ among indiangrass varieties.

Previous studies under different types of grasses, mostly cool-season grasses, have found that root biomass may not always differ among grass species or between monocultures and mixtures. For example, in two studies after 3 and 4 years, differences in root biomass among grass species mixtures and monocultures were not significant in a study in Germany $[16,40]$. However, mixtures increased root biomass relative to monocultures after 11 years, suggesting that differences may develop in the longer term [40]. The total soil-profile root biomass in switchgrass monocultures, in this study, was comparable with that reported in a 3-year study of switchgrass for the 0 - to $90-\mathrm{cm}$ depth in southern Washington [7] and a 3-year study of switchgrass for the 0- to $110-\mathrm{cm}$ depth in central North Dakota [14]. In our study, the lack of significant differences between mixtures and monocultures may be due to similar rooting patterns across the species studied.

\section{Soil organic carbon and other soil properties}

Soil organic C (Fig. 1) and total N (Table 2) pools did not differ at any soil depth among grass monocultures and mixtures after 6 years of management. Cumulative SOC pool for the 100-cm depth was $98.09 \pm 8.82 \mathrm{Mg} \mathrm{ha}^{-1}$ and cumulative total $\mathrm{N}$ pool was $10.74 \pm 0.74 \mathrm{Mg} \mathrm{ha}^{-1}$. Results did not support our hypothesis that mixtures will improve SOC and other soil properties compared with monocultures after 6 years. As in experiment I, the soil under experiment II was highly productive, which may have reduced treatment effects. Our results are consistent with two previous studies of warm-season grasses. After 3 years, SOC pools among a switchgrass monoculture, a 4-grass species mixture, and a 10-species mixture of native grasses were similar in Virginia [6]. Also, after 11 years, big bluestem, indiangrass, and little bluestem [Schizachyrium scoparium (Michx)] did not increase SOC relative to C3-grass species in Michigan [41], suggesting that even after a long period of time, SOC pools among perennial grasses may not differ.

The soil C:N ratio among grass monocultures and mixtures did not differ, which suggests that soil organic matter decomposition rates among the grass treatments studied were similar. Averaged across grass treatments, C:N ratio was $8.97 \pm 3.41$ for the 0 - to $100-\mathrm{cm}$ depth. Nitrogen fertilization often reduces soil C:N ratio in croplands, but studies on the effect of warm-season grass monocultures and mixtures on $\mathrm{C}: \mathrm{N}$ ratio are not available to compare with our results.

The SOC pool $\left(98.09 \pm 8.82 \mathrm{Mg} \mathrm{C} \mathrm{ha}{ }^{-1}\right)$ at 0 to $100 \mathrm{~cm}$ in this study after 6 years was similar to that $\left(116.6 \pm 59.4 \mathrm{Mg} \mathrm{C} \mathrm{ha}^{-1}\right)$ found in a nearby switchgrass experiment after 9 years [13]. These results appear to indicate that, after 6 years, grass monocultures and mixtures stored similar amounts of SOC to that under switchgrass monocultures after 9 years. Also, after 5 years, SOC concentration among switchgrass, miscanthus, and

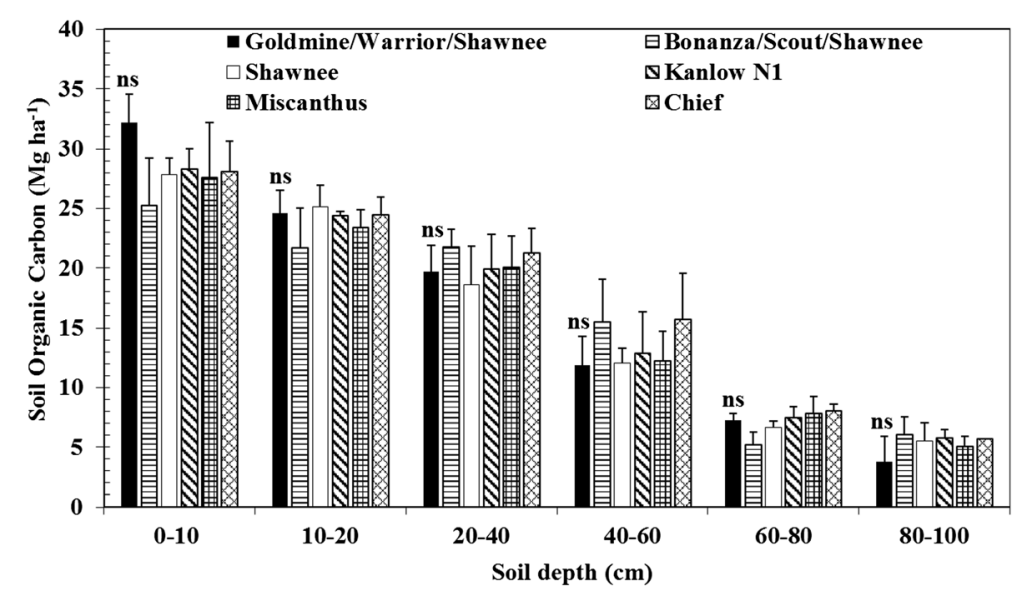

Fig. 1 Soil-profile organic C distribution under perennial warm-season grass monocultures [switchgrass (cv. Shawnee, Kanlow N1), indiangrass (Chief) and Mxg] and mixtures [(big bluestem (Goldmine) + indiangrass (Warrior) + switchgrass (Shawnee) and big bluestem (Bonanza) + indiangrass (Scout) + switchgrass (Shawnee)] on a Tomek silt loam in eastern Nebraska after 6 years of management. No significant differences (ns) were detected on SOC among grass monocultures and mixtures. Error bars are standard deviation values 
Table 2 Total nitrogen response to perennial warm-season grass monocultures and mixtures on a Tomek silt loam in eastern Nebraska after 6 years of management

\begin{tabular}{lllllll}
\hline Treatments & \multicolumn{7}{l}{ Total nitrogen $\left(\mathrm{Mg} \mathrm{ha}^{-1}\right)$} \\
\cline { 2 - 7 } & \multicolumn{1}{l}{ Depths $(\mathrm{cm})$} \\
\cline { 2 - 7 } & $0-10$ & $10-20$ & $20-40$ & $40-60$ & $60-80$ & $80-100$ \\
\hline Grass mixture 1 & $3.03 \mathrm{~ns}$ & 2.67 & 2.01 & 1.56 & 1.02 & 1.6 \\
Grass mixture 2 & 2.41 & 2.11 & 1.85 & 1.41 & 1.05 & 0.84 \\
Shawnee & 2.64 & 2.46 & 1.93 & 1.21 & 1.15 & 0.75 \\
Kanlow N1 & 2.63 & 2.48 & 2.25 & 1.45 & 1.16 & 1.27 \\
Miscanthus (Mxg) & 2.63 & 1.95 & 1.99 & 1.41 & 1.03 & 0.81 \\
Chief & 2.49 & 2.6 & 2.09 & 1.77 & 1.23 & 1.55 \\
LSD 0.05 & 0.58 & 0.69 & 0.52 & 0.47 & 0.49 & 0.89
\end{tabular}

Perennial warm-season grass monocultures [switchgrass (cv. Shawnee, Kanlow $\mathrm{N} 1$ ), indiangrass (Chief) and Mxg] and grass mixture 1[big bluestem (Goldmine) + indiangrass (Warrior) + switchgrass (Shawnee)] and grass mixture 2 [big bluestem (Bonanza) + indiangrass (Scout) + switchgrass (Shawnee)]. Means among grass treatments were not significantly different (ns)

big bluestem monocultures did not differ in a study in Kansas [11], suggesting that perennial warm-season grasses regardless of species may have similar potential in accumulating $\mathrm{SOC}$ in this region. Also, grass monocultures and mixtures did not affect soil bulk density. Bulk density averaged across grass monocultures and mixtures was $1.40 \pm 0.09 \mathrm{~g} \mathrm{~cm}^{-3}$ at 0 to $10 \mathrm{~cm}, 1.61 \pm$ $0.13 \mathrm{~g} \mathrm{~cm}^{-3}$ at 10 to $20 \mathrm{~cm}, 1.60 \pm 0.07 \mathrm{~g} \mathrm{~cm}^{-3}$ at 20 to 40 $\mathrm{cm}, 1.62 \pm 0.12 \mathrm{~g} \mathrm{~cm}^{-3}$ at 40 to $60 \mathrm{~cm}, 1.61 \pm 1.10 \mathrm{~g} \mathrm{~cm}^{-3}$ at 60 to $80 \mathrm{~cm}$ and $1.70 \pm 0.07 \mathrm{~g} \mathrm{~cm}^{-3}$ at 80 to $100 \mathrm{~cm}$.

\section{Conclusions}

Four years of inorganic (NPK) fertilization of switchgrass in a silty loam in eastern Nebraska did not affect root biomass and soil properties. Similarly, 6-year-old stands of simple mixtures of big bluestem, indiangrass, and switchgrass had no significant impact on the SOC pool, total $\mathrm{N}$, and $\mathrm{C}: \mathrm{N}$ ratio compared with monocultures. However, Chief indiangrass had lower root biomass compared to all other grasses except miscanthus. As mentioned earlier, aboveground biomass production of perennial warm-season grasses often reaches full potential in about 5 years [37]. Thus, our results suggest that there could be limited or no impacts of inorganic fertilization and mixtures on root production and soil properties within the above timeframe and soil type. We hypothesize that the lack of root biomass and soil properties' response to fertilization may be attributed to the use of a highly productive soil. The lack of differences in root biomass among the four warm-season grasses (big bluestem, indiangrass, switchgrass, and miscanthus) suggests that these grasses have similar rooting characteristics except Chief indiangrass. Further study is warranted to test the longer term effects of fertilization and mixtures on root production and soil properties.

\section{Competing interests}

The authors declare that they have no competing interests.

\section{Authors' contributions}

LCK and HB-C collected, prepared, analyzed the soil samples and prepared the manuscript. RM and WS designed and managed the field experiments and contributed to the critical review and inputs into the manuscript. All authors read and approved the final manuscript.

\section{Acknowledgements}

This research was supported by funding from the North Central Regional Sun Grant Center at South Dakota State University through a grant provided by the US Department of Agriculture under award number 2010-38502-21861.

\section{Author details}

${ }^{1}$ Department of Agronomy and Horticulture, University of Nebraska-Lincoln, Lincoln, NE 68583, USA. ${ }^{2}$ Grain, Forage, and Bioenergy Research Unit USDA-ARS, University of Nebraska-Lincoln, Lincoln, NE 68583, USA.

Received: 14 August 2015 Accepted: 25 November 2015 Published online: 07 January 2016

\section{References}

1. Adler PR, Del Grosso SJ, Parton WJ (2007) Life-cycle assessment of net greenhouse-gas flux for bioenergy cropping systems. Ecol Appl 17:675-691

2. Blanco-Canqui $H$, Shapiro CA, Wortmann CS, Drijber RA, Mamo M, Shaver TM, Ferguson RB (2013) Soil organic carbon: the value to soil properties. J Soil Water Conserv 68:129A-134A

3. Blanco-Canqui H, Gilley JE, Eisenhauer DE, Jasa PJ, Boldt A (2014) Soil carbon accumulation under switchgrass barriers. Agron J 106:2185-2192

4. Blanco-Canqui $\mathrm{H}$ (2010) Energy crops and their implications on soil and environment. Agron J 102:403-419

5. Blanco-Canqui H, Ferguson RB, Shapiro CA, Drijber RA, Walters DT (2014) Does inorganic nitrogen fertilization improve soil aggregation? Insights from long-term tillage experiments. J Environ Qual 43:995-1003

6. Bonin CL, Lal R, Tracy BF (2014) Evaluation of perennial warm-season grass mixtures managed for grazing or biomass production. Crop Sci 54:2373-2385

7. Collins HP, Smith JL, Fransen S, Alva AK, Kruger CE, Granatstein DM (2010) Carbon sequestration under irrigated switchgrass (Panicum virgatum L.) production. Soil Sci Am J 74:2049-2058

8. Cong W, Ruijven J, Mommer L, De Deyn BG, Berendse F, Hoffland E (2014) Plant species richness promotes soil carbon and nitrogen stocks in grasslands without legumes. J Ecol 102:1163-1170

9. de Kroon H, Hendriks MJ, van Ruijven J, Ravenek FM, Padilla E, Jongejans EJ, Visser W, Mommer L (2012) Root responses to nutrients and soil biota: drivers of species coexistence and ecosystem productivity. J Ecol 100:6-15

10. Del Grosso SJ, Mosier AR, Parton WJ, Ojima DS (2005) DAYCENT model analysis of past and contemporary soil $\mathrm{N}_{2} \mathrm{O}$ and net greenhouse gas flux for major crops in the USA. Soil Tillage Res 83:9-24

11. Evers BJ, Blanco-Canqui H, Staggenborg SA, Tatarko J (2013) Dedicated bioenergy crop impacts on soil wind erodibility and organic carbon in Kansas. Agron J 105:1271-1276

12. Fornara DA, Tilman D (2008) Plant functional composition influences rates of soil carbon and nitrogen accumulation. J Ecol 96:314-322

13. Follett RF, Vogel KP, Varvel GE, Mitchell RB, Kimble J (2012) Soil carbon sequestration by switchgrass and no-till maize grown for bioenergy. Bioenergy Res 5:866-875

14. Frank AB, Berdahl JD, Hanson JD, Liebig MA, Johnson HA (2004) Biomass and carbon partitioning in switchgrass. Crop Sci 44:1391-1396

15. Garten CT Jr, Brice DJ, Castro HF, Graham RL, Mayes MA, Phillips JR, Post WM III, Schadt CW, Wullschleger SD, Tyler DD, Jardine PM, Jastrow JD, Matamala R, Miller RM, Moran KK, Vugteveen TW, Izaurralde RC, Thomson AM, West TO, Amonette JE, Bailey VL, Metting FB, Smith JL (2011) Response of "Alamo" switchgrass tissue chemistry and biomass to nitrogen fertilization in West Tennessee, USA. Agric Ecosyst Environ 140:289-297 
16. Gastine A, Scherer-Lorenzen M, Leadley PW (2003) No consistent effects of plant diversity on root biomass, soil biota and soil abiotic conditions in temperate grassland communities. Applied Soil Ecol 24:101-111

17. Gee GW, Or D (2002) Particle-size analysis. p. 255-293. In: Dane JH, Topp GC (eds) Methods of soil analysis. Part 4. SSSA Book Ser. 5. SSSA, Madison

18. Haynes RJ, Naidu R (1998) Influence of lime, fertilizer, and manure applications on soil organic matter content and soil physical conditions: a review. Nutr Cycling Agroecosyst 51:123-137

19. Heggenstaller AH, Moore KJ, Liebman M, Anex RP (2009) Nitrogen influences biomass and nutrient partitioning by perennial, warm-season grasses. Agron J 101:1363-1371

20. Hyvonen R, Persson T, Andersson S, Olsson B, Agren Gl, Linder S (2008) Impact of long-term nitrogen addition on carbon stocks in trees and soils in northern Europe. Biogeochemistry 89:121-137

21. Jung JY, Lal R (2011) Impacts of nitrogen fertilization on biomass production of switchgrass (Panicum virgatum L.) and changes in soil organic carbon in Ohio. Geoderma 166:145-152

22. Jung JY, Lal R, Jastrow JD, Tyler DD (2011) Nitrogenous fertilizer effects on soil structural properties under switchgrass. Agric Ecosyst Environ $141: 215-220$

23. Kering MK, Butler TJ, Biermacher JT, Guretzky JA (2012) Biomass yield and nutrient removal rates of perennial grasses under nitrogen fertilization. Bioenerg Res 5:61-70

24. Khan SA, Mulvaney RL, Ellsworth TR, Boast CW (2007) The myth of nitrogen fertilization for soil carbon sequestration. J Environ Qual 36:1821-1832

25. Lemus R, Parrish DJ, Abaye O (2008) Nitrogen-use dynamics in switchgrass grown for biomass. Bioenergy Res 1:153-162

26. Liebig MA, Varvel GE, Doran JW, Wienhold BJ (2002) Crop sequence and nitrogen fertilization effects on soil properties in the western Corn Belt. Soil Sci Soc Am J 66:596-601

27. Lu M, Zhou XH, Luo YQ, Yang YH, Fang CM, Chen JK, Li B (2011) Minor stimulation of soil carbon storage by nitrogen addition: a meta-analysis. Agr Ecosyst Environ 140:234-244

28. Ma Z, Wood CW, Bransby DI (2000) Impacts of soil management on root characteristics of switchgrass. Biomass Bioenergy 18:105-112

29. Ma Z, Wood CA, Bransby DI (2000) Soil management impacts on soil carbon sequestration by switchgrass. Biomass Bioenergy 18:469-477

30. Mack MC, Schuur EAG, Bret-Harte MS, Shaver GR, Chapin FS (2004) Ecosystem carbon storage in arctic tundra reduced by long-term nutrient fertilization. Nature 431:440-443

31. McLaughlin SB (1992) New Switchgrass Biofuels Research Program for the Southeast, pp. 111-115. In: Proceedings of the Annual Automotive Technology Development Contractors' Coordination Meeting. SAE International, Warrendale

32. Mommer L, van Ruijven J, de Caluwe H, SmitTiekstra AE, Wagemaker CAM, Ouborg NJ, Bogemann GM, van der Weerden GM, Berendse F, de Kroon H (2010) Unveiling below-ground species abundance in a biodiversity experiment: a test of vertical niche differentiation among grassland species. J Eco 98:1117-1127

33. Neff JC, Townsend AR, Gleixner G, Lehman SJ, Turnbull J, Bowman WD (2002) Variable effects of nitrogen additions on the stability and turnover of soil carbon. Nature 419:915-917

34. Nelson DW, Sommers LE (1996) Total carbon, organic carbon and organic matter: laboratory methods. In: Sparks DL et al (eds) Methods of soil analysis. Part3. SSSA Book Ser 5. SSSA, Madison, pp 961-1010

35. Nimmo JR, Perkins KS (2002) Aggregate stability and size distribution. In: Dane JH, Topp GC (eds) Methods of soil analysis. Part 4. SSSA Book Ser. 5. SSSA, Madison, pp 317-327

36. Newton GL, Bernard JK, Hubbard RK, Allison JR, Lowrance RR, Gascho GJ, Gates $\mathrm{RN}$, Vellidis $\mathrm{G}$ (2003) Managing manure nutrients through multi-crop forage production. J Dairy Sci 86:2243-2252

37. Perrin R, Vogel K, Schmer M, Mitchell R (2008) Farm-scale production cost of switchgrass for biomass. Bioenerg Res 1:91-97

38. Peterson RG, Colvin LD (2002) Sampling. In: Dane JH, Topp GC (eds) Methods of soil analysis. Part 4. Agron. Monogr. 5. SSSA, Madison

39. Pregitzer KS, Burton AJ, Zak DR, Talhelm AF (2008) Simulated chronic nitrogen deposition increases carbon storage in northern temperate forests. Glob Chang Biol 14:142-153

40. Ravenek JM, Bessler H, Engels C, Scherer-Lorenzen M, Gessler A, Gockele A, De Luca E, Temperton VM, Ebeling A, Roscher C (2014) Long-term study of root biomass in a biodiversity experiment reveals shifts in diversity effects over time. Oikos 123:1528-1536

41. Reich PB, Knops J, Tilman D, Craine J, Ellsworth D, Tjoelker M, Lee T, Wedin D, Naeem S, Bahauddin D, Hendrey G, Jose S, Wrage K, Goth J, Bengston W (2001) Plant diversity enhances ecosystem responses to elevated $\mathrm{CO}_{2}$ and nitrogen deposition. Nature 410:809-812

42. Robinson DL (1996) Fertilization and nutrient utilization in harvested forage systems - southern forage crops. In: Joost RE, Roberts CA (eds) Nutrient cycling in forage systems., pp 65-92

43. SAS Institute (2012) The analyst applications. SAS Inst, Cary

44. Thomas GW (1996) Soil pH and soil acidity. In: Sparks DL (ed) Methods of soil analysis. Part 3. SSSA Book Ser. 5. SSSA, Madison, pp 475-490

45. Tisdall JM, Oades JM (1982) Organic matter and water stable aggregates in soils. J Soil Sci 33:141-163

46. Van Noordwijk M, Brouwer G (1997) Roots as sinks and sources of nutrients and carbon in agricultural systems. In: Brussaard L, Ferrera-Cerrato R (eds) Soil ecology in sustainable agricultural systems. Adv Agroeco CRC-Press, Boca Raton, pp 71-89

47. Vogel KP, Brejda JJ, Walters DT, Buxton DR (2002) Switchgrass biomass production in the Midwest USA: harvest and nitrogen management. Agron J 94:413-420

48. Von Felten S, Schmid B (2008) Complementarity among species in horizontal versus vertical rooting space. J Plant Ecol 1:33-41

\section{Submit your manuscript to a SpringerOpen ${ }^{\odot}$ journal and benefit from:}

- Convenient online submission

Rigorous peer review

- Immediate publication on acceptance

- Open access: articles freely available online

- High visibility within the field

- Retaining the copyright to your article

Submit your next manuscript at $>$ springeropen.com 